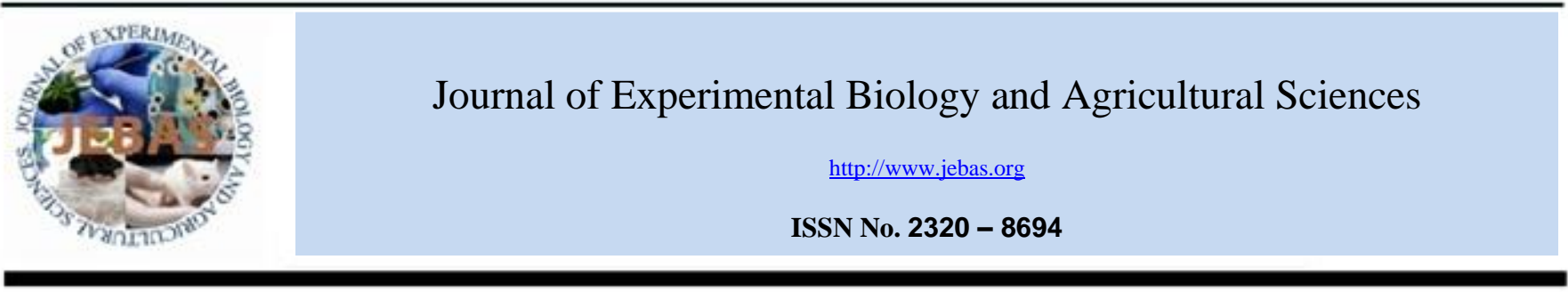

\title{
EQUINE BRUCELLOSIS: REVIEW ON EPIDEMIOLOGY, PATHOGENESIS, CLINICAL SIGNS, PREVENTION AND CONTROL
}

\section{Kumaragurubaran Karthik ${ }^{1, *}$, Govinthasamy Prabakar $^{2}$, Ramasamy Bharathi ${ }^{1}$, Sandip Kumar Khurana $^{3}$ and Kuldeep Dhama ${ }^{2}$}

\footnotetext{
${ }^{1}$ Tamil Nadu Veterinary and Animal Sciences University, Chennai- 51, India

${ }^{2}$ Indian Veterinary Research Institute, Izatnagar, Bareilly, U.P., India
}

${ }^{3} \mathrm{NRCE}$, Hisar, Haryana, India

Received - November 03, 2016; Revision - November 25, 2016; Accepted - December 02, 2016

Available Online - December 04, 2016

DOI: http://dx.doi.org/10.18006/2016.4(Spl-4-EHIDZ).S151.S160

KEYWORDS
Brucellosis
Equine
B. abortus
Poll evil
Fistulous withers
LAMP

\begin{abstract}
Brucellosis is one of the major zoonotic diseases that affect several domestic animals, wild animals and also marine mammals. Though there is no specific Brucella sp. that can affect horses, B. abortus and B. suis can affect horses naturally and $B$. canis experimental infection has also been reported in equines. Brucellosis in equines is characterized by two conditions namely Poll evil and fistulous withers. Organism has its predilection for joints, ligaments and tendons in case of equines and causes inflammatory conditions leading to formation of fistula. Equine brucellosis has been documented from several parts of the world and prevalence has been reported time to time mostly based on serological diagnosis. Diagnosis of brucellosis mainly depends on serological methods though isolation of the organism is the gold standard. Due to hazardous nature of the pathogen, tests like Rose Bengal plate agglutination test, Standard tube agglutination test and other serological assays are commonly employed. Isothermal amplification assay like LAMP are gaining momentum these years due to swiftness in diagnosis of the pathogen. LAMP with high specificity and sensitivity for detection of Brucella spp. and also B. abortus has been developed in the recent years. Prevention and control of brucellosis is of utmost important to halt the spread of the organism to other animals and human. Trauma is a major reason for predisposition of poll evil and fistulous withers hence proper fitting of saddle will help to prevent the disease. Housing and feeding the horses separately can prevent spread of disease from cattle. The present review discusses equine brucellosis, its epidemiology, pathogenesis, clinical signs along with appropriate prevention and control strategies to be adapted.
\end{abstract}

* Corresponding author

E-mail: karthik_2bvsc@yahoo.co.in (Kumaragurubaran Karthik)

Peer review under responsibility of Journal of Experimental Biology and Agricultural Sciences.

Production and Hosting by Horizon Publisher India [HPI] (http://www.horizonpublisherindia.in/).

All rights reserved.
All the article published by Journal of Experimental Biology and Agricultural Sciences is licensed under a Creative Commons Attribution-NonCommercial 4.0 International License Based on a work at www.jebas.org.

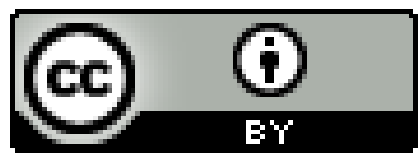




\section{Introduction}

Brucellosis is a major zoonotic disease caused by the bacterium of the genus Brucella of which several species has been listed to cause disease in domestic and wild animals. History shows that the disease was first identified in Malta in the year 1887 by Sir David Bruce who isolated Brucella melitensis, the then Micrococcus melitensis from a soldier died due to Maltese fever (Godfroid et al., 2005). Recent years has seen this bacterium as a pathogen causing disease in sea mammals thus showing the long journey of this pathogen from Malta to Marine. There are eleven Brucella species namely $B$. abortus (cattle), B. melitensis (sheep and goats), B. ovis (sheep), B. suis (hogs), B. canis (dogs), B. neotomae (wood rats), B. microti, B. maris, B. ceti and B. pinnipedialis (marine mammals) and $B$. inopinata (isolated recently from women breast implant) (Verger et al., 1987; Foster et al., 2007; Scholz et al., 2008).

These eleven Brucella spp. do not follow the strict rule towards host specificity as they can infect other animals and also human beings hence this pathogen is considered as an important zoonotic organism. B. abortus and B. suis affects wild animals and reports regarding $B$. melitensis infection in wild animals are less (Rhyan, 2000; Godfroid \& Kasbohrer, 2002). There is no specific Brucella sp. that can cause disease particularly in horses. All the documented reports of brucellosis in horse are mainly by the cattle pathogen, $B$. abortus and to a milder extent $B$. suis biovar 3 (Lucero et al., 2008; Colavita et al., 2016).

Members of the genus Brucella are facultative intracellular gram negative cocco-bacilli or short rods measuring around 0.6 to $1.5 \mu \mathrm{m}$ long and 0.5 to $0.7 \mu \mathrm{m}$ width. Brucella genus neither form capsules nor spores nor motile though carry the genes for motility (except the chemotactic system that helps in assembling a functional flagellum) (Fretin et al., 2005). Brucella genus is classified phylogenetically within the $\alpha_{2}$ subdivision of Proteobacteria which comprises of Agrobacterium, Bartonella, Ochrobactrum, Rhizobium, Rhodobacter, and Rickettsia (Moreno et al., 1990). Genome of B. abortus has two circular chromosomes of $2.1 \mathrm{Mb}$ and 1.5 Mb size without plasmids (Michaux et al., 1993; MichauxCharachon et al., 1997). Recent years has seen the completion of genome of B. abortus (Sanchez et al., 2001), B. melitensis (GenBank NC 003317 and NC 003318) (DelVecchio et al., 2002) and B. suis (GenBank NC 002969) thus increasing the opportunity for understanding the pathogenicity of Brucella.

Brucellosis mainly causes reproductive diseases in various animals, and in horses the clinical manifestation is termed as "poll-evil" or "fistulous withers" due to the inflammation of supraspinous bursa and connective tissue, leading to abscess formation and fistulation in the affected region and occasionally abortions and other reproductive problems are also reported (Denny, 1972). B. abortus has been reported worldwide causing infection in domestic animals though some countries like Australia, Canada, Japan, Israel and New Zealand have controlled the disease (Nicoletti, 2007). Reports shows that age, breed and sex specificity does not exist for brucellosis in equine though more cases are documented in horses above 3 years of age (Nicoletti, 2007).

\section{Epidemiology}

Three species of Brucella namely B. abortus, B. suis and $B$. canis have been incriminated to infect horses, of which $B$. abortus and $B$. suis have been reported with natural infection and $B$. canis infection has been reported with experimental infection (Hagler et al., 1982).

Brucella antibodies have been reported from several parts of the world at various time frames showing that horses get infected from other animals. A study in Brazil was conducted where 123 crossbred cart horse serum samples were collected from a period April 2005 to June 2006. These samples were subjected to Rose Bengal Plate agglutination Test (RBPT) which showed eight animals $(6.5 \%)$ to be positive for brucella antibodies. This study did not report isolation of the pathogen and the seropositive animals did not show any clinical manifestation of the disease (Antunes et al., 2013). A multispecies farm in Nigeria comprising of different livestock species like cattle, horse, goat and sheep was investigated for $B$. abortus infection status. This study revealed that all the seven horses under the study were found positive by RBPT. Vaginal samples from 6 horses were subjected for isolation of $B$. abortus which showed that two samples were positive for $B$. abortus. This study is the first report of isolation of the pathogen from non clinical cases from horse (Bertu et al., 2015). The report of this study warrants attention as disease free horses can also play role in transmission of the pathogen to other animals and also to human. Several other studies have been conducted earlier in Nigeria to investigate the presence of brucellosis in horses which documented $8.4 \%$ (14 positive of 166 animals) and $14.7 \%$ (11 samples out of 75 horses) which were lesser compared to the recent survey documenting $100 \%$ positivity (Bale \& Kwanashie, 1984; Ehizibolo et al., 2011). Multispecies housing can increase the possibility of disease spread. Already there are established reports that horse to horse or other animals is a less likely event and these animals do not excrete the organism (Corbel \& Henry, 1983; Macmillan \& Cockrem, 1985). Sadiq et al. (2013) reported 5.5\% seropositivity of brucellosis by RBPT and Microtiter Serum Agglutination Test in donkeys from Borno and Yobe states of Nigeria.

A very recent study conducted on the Mambilla plateau of Taraba state, Nigeria showed $16 \%$ prevalence of brucellosis and adult horses were affected more that young animals (Ardo \& Abubakar, 2016). Another study conducted in the same Taraba state of Jalingo region showed 7 animals out of 90 adult horses screened by RBPT (Ardo et al., 2016). 
Studies conducted in Iran also reported isolation of B. abortus from infected horses and serological diagnosis by RBPT, standard tube agglutination test (STAT) and 2-mercapto ethanol (2ME) showed $2.5 \%$ to $12 \%$ prevalence (Tahamtan et al., 2010). Another study in the Hamadan region of Iran showed $0.5 \%$ prevalence by RBPT and STAT (Ghobadi \& Salehi, 2013). Positive animal in this study was also in close contact with other animals hence there was a higher chance of infection. Earlier study in the Mashhad region of Iran also showed $2.5 \%$ positive cases (Tahamtan et al., 2010).

An epidemiological survey was conducted in Peshawar district of Pakistan employing 500 serum samples from horses $(\mathrm{n}=$ 196), donkeys $(n=267)$ and mules $(n=37)$ collected during a time period of January to December, 2012. Higher prevalence $(71.93 \%)$ was reported in horses than donkeys $(63.67 \%)$ and mules (5.4\%). Study also reported females and animals of 5-11 years were affected most (Safirullah et al., 2014). Younger animals tend to clear the pathogen faster though there is possibility of latent infection which may be the reason that the study had higher infection rate among older animals (Quinn et al., 2004). Sex hormone and erythritol tend to increase as the age advances and this may be another reason brucella infection is seen in older animals after sexual maturity (Radostits et al., 2000).

Serum samples of 227 equines (178 donkeys, 43 horses and 6 mules) collected in the Mossoró, Rio Grande do Norte, Brazil were subjected to RBPT, STAT and 2 ME showed $1.76 \%$ prevalence of brucellosis in horse serum (Dorneles et al., 2013). A massive survey was conducted recently employing serum samples of 6,439 animals comprising samples from 5,292 horses, 110 donkeys and 1,037 mules from 1936 herds of Minas Gerais State, Brazil over a period of September 2003 and March 2004 (Junqueira et al., 2015). RBPT and STAT was performed which showed that 70 horses out of 5,292 animals to be positive (1.32\%), 1 out of 110 donkeys $(0.91 \%)$ and 14 out of 1,037 mules $(1.35 \%)$. This study documented that males (52 out of 4106 males) had higher sero-positivity compared to female (33 out of 2333 females) (Junqueira et al., 2015).

A study in Western Sudan employing serum samples from 346 horses and 28 donkeys showed $4.9 \%$ and $3.6 \%$ prevalence of brucellosis in horses and donkey (Musa, 2004). A total of 1954 serum samples (horses 782 and donkeys 1172) were collected from Sanliurfa and Diyarbakir provinces of South-East Turkey and were subjected to RBPT. Prevalence was higher in horses (13.68\%) than donkeys (6.05\%) (Tel et al., 2011). Several other workers have earlier studied the prevalence of brucellosis in horse in various regions of Turkey. Solmaz et al. (2004) reported $60.59 \%$ prevalence of brucellosis by RBPT in horses in the Van province of Turkey. Göz et al. (2007) reported 9.5\% horses to be positive by STAT in Hakkari region of Turkey.

Brucella organism is to an extent resilient which has been recovered from manure and fetal samples even after 2 months when kept in cool weather condition. Exposure to sunlight for few hours kills the bacteria and they are also readily killed by commonly used disinfectants (Glynn \& Lynn 2008).

\section{Pathogenesis}

The major route of entry of the pathogen into the host (equines) is through the consumption of feed contaminated with $B$. abortus and contact infection from cattle has been reported by several workers (Denny 1973; O'Sullivan 1981; Ocholi et al., 2004). There prevails mystery regarding the role played by horse in the transmission of infection to other horses or to other animals/ humans. Hence there is no clear evidence that supports that horse's act as a ware house/ reservoir for transmission of brucellosis in endemic areas (Acosta-Gonzalez et al., 2006).

Being a facultative intracellular pathogen, Brucella survives, multiplies and evades host immune mechanism simultaneously found developing inside phagocytic cells (Gorvel \& Moreno, 2006). Ecological niche inside the phagosomal compartment of host macrophages is conducive for the survival of brucellae and maintaining chronic infections depends upon the ability of surviving and replicating within these phagocytic cells (Roop et al., 2004; Neta et al., 2010) (Figure 1). Brucella infection occurs through ingestion and the organism enters the oral and pharyngeal cavities (Brinley et al., 1990). The bacteria are transported following penetration of the mucosal epithelium either free or within phagocytic cells to the regional lymph nodes through macrophages leading to spread and multiplication of organism in lymph nodes, spleen, liver, bone marrow, reproductive organs, tendon sheath and bursae occur (Canning et al., 1986; Riley et al., 1984; Memish et al., 2000; Adams, 2002). The capacity of Brucella to hide inside the macrophages makes it difficult to diagnose the disease and also hinder in the treatment of the disease (Glynn \& Lynn 2008).

\section{Clinical signs}

In equines, the clinical signs due to brucellosis are mostly noticed in the musculoskeletal system mainly as the organism localise in the bursae (causing septic bursitis), joints (causing septic arthritis) and tendon sheaths (causing septic tenosynovitis) (Denny, 1972, Denny,1973; Carrigan et al., 1987; Ocholi et al., 2004). Few reports regarding abortion, vertebral osteomyelitis and infertility in male horses have also been documented (Collins et al., 1971; Denny 1973). Most classical clinical signs observed in horses due to brucellosis are poll evil (septic supra-atlantal bursitis) and fistulous withers (septic supraspinatous bursitis). Draining sinuses are seen as these problems are chronic in case of equines (Crawford et al., 1990). An experimental infection of B. abortus instillation into the conjunctival sac was carried out in a horse to know the clinical signs. Serum antibody level was evident after 7 to 12 days of infection and intermittent bacteraemia was observed for 2 months (MacMillan et al., 1982). 


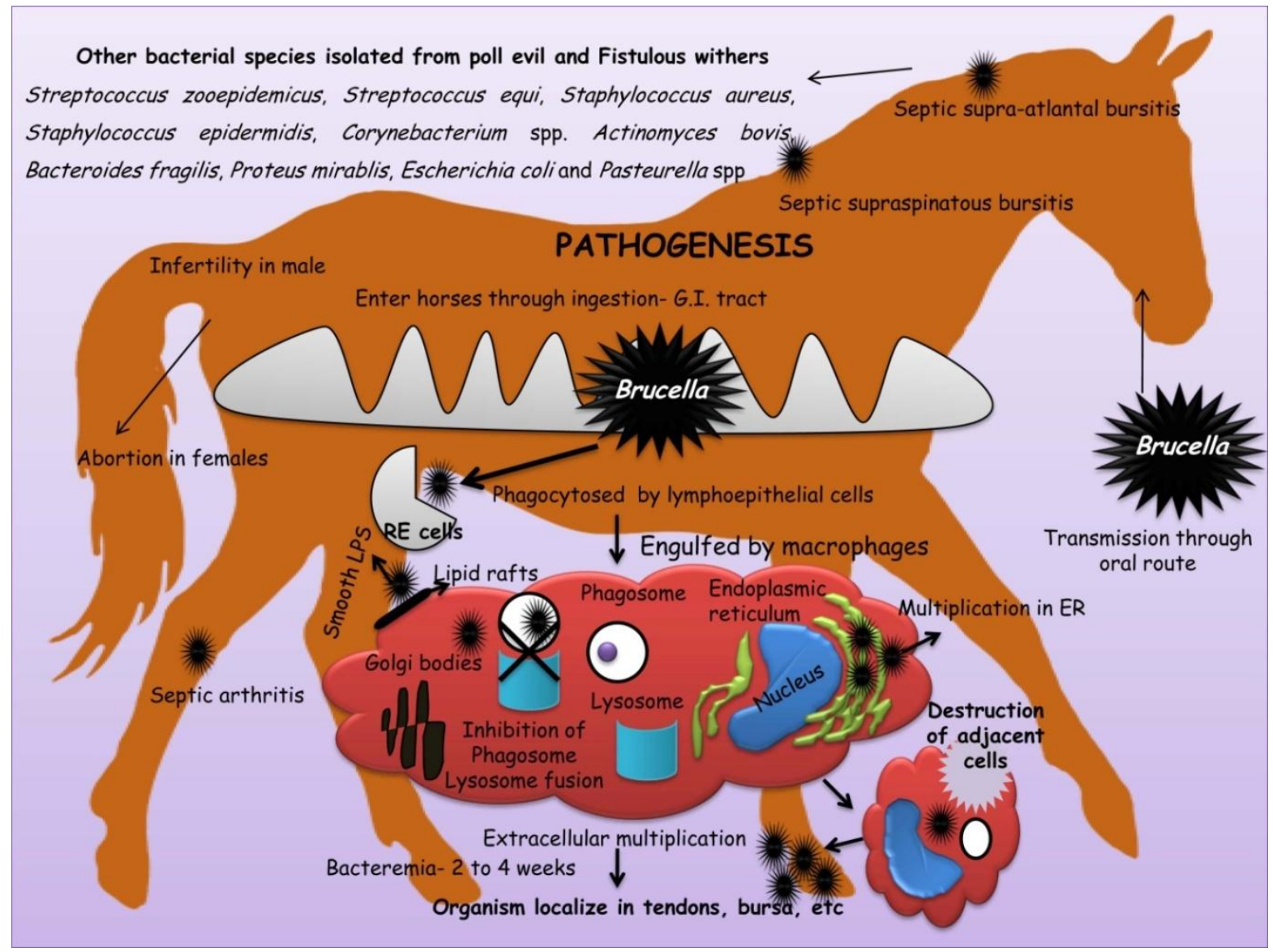

Figure 1 Pathogenesis and clinical signs of equine brucellosis.

Lesions are of granulomatous type were observed in lung, liver, testes and metatarsophalangeal synovial membranes (Megid et al., 2010). No apparent clinical signs were noted and female animals bred normally yielding negative results to isolation of organism (MacMillan \& Cockrem, 1986). B. abortus induced abortion in equines are not common though some documented reports state that mid to late term abortion may occur (McNutt \& Murray 1924; McCaughey \& Kerr 1967; Shortridge, 1967; Robertson et al., 1973; Hinton et al., 1977). Organism in the vaginal excretions does not last longer as compared to cattle.

Some authors reported the isolation of B. suis from aborted equine fetuses (McNutt \& Murray, 1924), horses affected with septic bursitis (Portugal et al., 1971) and also from the reproductive organs of mares without apparent clinical signs (Cvetnic et al., 2005).

\section{Diagnosis}

The gold standard test for diagnosis of Brucellosis is isolation and identification of the organism which needs 5-10\% carbon dioxide for its growth. Even with all the conditions conducive for the growth of Brucella, it will take around 3-5 days for a colony to appear. At times it may even take longer; hence culturing work is laborious and time consuming. The major setback in culturing is that Brucellosis is zoonotic and the handlers are always at the risk of infection (Karthik et al., 2014a). Hence it needs level 3 biocontainment facilities and highly skilled technical personnel for handling live culture (Alton et al., 1988).

Serological tests like Rose Bengal Plate Test (RBPT), Standard Tube Agglutination Test (STAT) and Enzyme Linked Immunosorbent Assay (ELISA) are commonly employed (Nicoletti, 2007). Other serological tests include complement fixation test (CFTs), 2-mercaptoethanol (2ME), buffered Brucella antigen tests (BBAT), Milk ring test (MRT), etc. (Acha \& Szyfres, 2003; Godfroid et al., 2010). These tests are inexpensive, fast and sensitive but not necessarily highly specific, antibodies may cross react with Yersinia enterocolitica serotype O:9, Escherichia coli O: 157, Francisella tularensis, Salmonella urbana O: 30, Vibrio cholerae, and others (Radostits et al., 2000).

Molecular techniques like PCR has been employed with various samples like blood, serum tissues from aborted foetus, semen and milk for diagnosis of brucellosis (Fekete et al., 
1992; Leal-Klevezas et al., 1995; Queipo-Ortuno et al., 1997; Amin et al., 2001; Kanani, 2007). More recently, real-time PCR has been used for detection of Brucella, offering improvement in detection times and specificity (QueipoOrtuno et al., 2005). Real-time PCR is the latest method used in which hybridization probes are used to increase specificity (Bricker, 2002; Probert et al., 2004; Elfaki et al., 2005).

Isothermal amplification assay has the advantage of employing a set temperature for amplification of DNA, reducing the time for amplification and also there is no need for post amplification protocol for result visualization (Dhama et al., 2013). LAMP for the Brucella was developed against Brucella cell surface protein (bcsp)31 gene and omp25 gene and sensitivity of both LAMP assay was higher than PCR (Ohtsuki et al., 2008; Lin et al., 2011). LAMP with visual detection based on calcein has also been developed targeting the same omp 25 (Pan et al., 2011). Reports regarding development of LAMP targeting IS711 genes and real time quantitative LAMP are available (Pérez-Sancho et al., 2013). Visual LAMP targeting omp25 gene including loop primers was developed recently that can detect all Brucella spp. Developed LAMP assay with loop primers was 10 fold more sensitive than commonly employed PCR (Karthik et al., 2016). LAMP assay has the intrinsic property of product carry over contamination hence a novel closed tube LAMP assay was also developed for detection of Brucella spp. (Karthik et al., 2014b). LAMP assay for specific diagnosis of $B$. abortus was also developed which was 100 fold more sensitive than the commonly employed PCR (Karthik et al., 2014c). Severity of bone damage in cases of poll evil and fistulous withers can be identified by radiography.

\section{Poll evil and fistulous withers}

Poll evil and fistulous withers are chronic inflammatory conditions affecting supra-atlantal bursa and supraspinatus bursa and its associated tissues respectively (Gaughan et al., 1988; Rashmir-Raven et al., 1990; Cohen et al., 1992). The term fistula refers to draining wound from a normally closed structure, through the skin and fistulous withers is an infection of the bursa overlying the spines of the withers by usually caused by Brucella sp. in horse. Though B. abortus has been incriminated as the major cause for this condition, there are other pathogens/ wound which also plays role in causing this condition in horses. Other pathogens like Streptococcus zooepidemicus, Streptococcus equi, Staphylococcus aureus, Staphylococcus epidermidis, Corynebacterium spp. Actinomyces bovis, Bacteroides fragilis, Proteus mirablis, Escherichia coli and Pasteurella spp. have also been isolated from horses suffering from fistulous withers (Cohen et al., 1992; Hawkins \& Fessler, 2000). Signs of fistulous withers include single or multiple draining tracts and in some case disseminated swelling in the wither region without drainage. Walls of the bursa gets thickened carrying clear, thick fluid which is of straw coloured (Megid et al., 2010). Initial signs include pain, swelling, heat at the bursal region leading to stiffness of the neck. Later stages the bursa ruptures and pus material gets discharged through one or more opening. These fistulas may heal slowly and there are always chances that they reappear (Cohen et al., 1992). Few years back researchers have found an Iron Age horse cranium from Tuva Republic, Central Asia and the cranium had occipital lesions, cavities around the nuchal ligament attachment site was noted in the skull which may be due to inflammation followed by necrosis (Bendrey et al., 2011). The researchers concluded that condition is poll evil originating due to bacterial cause. Authors discussed that this case may be due to $B$. abortus the common cause of poll evil in horses. Thus this study shows that the pathogen existed long back causing poll evil in horses (Bendrey et al., 2011).

Drainage of the infected tissue (poll evil and fistulous withers) and treatment with systemic antibiotics can be employed to treat brucellosis in horse. Chloramphenicol, tetracyclines, streptomycin and some sulphonamides are commonly used for treatment of Brucellosis but these antimicrobials cannot penetrate the infected tissues (Nicoletti, 2007). Clofazimine has been reported to have good effect in the treatment of brucellosis in equines (Knottenbelt et al., 1989). B. abortus S19 vaccine has also be used with good effect for treatment of brucellosis with the regimen ranging from one dose to three doses at 10 days interval (Denny, 1973; Gardner et al., 1983; Cohen et al., 1992; Nicoletti, 2007). Use of this vaccine for treatment also involves local and systemic reactions and death has been reported in a horse that received intra venous injection (Denny, 1973; Cohen et al., 1992). Periodical drainage, cleaning the region with antiseptics and dimethyl sulphoxide will aid to control further complications of poll evil and fistulous withers (Cohen et al., 1992).

\section{Prevention and control}

a. In most of the instances horse gets brucellosis when they are housed or allowed for grazing together with cattle. Hence horse should be housed or allowed for grazing away from cattle suspected for brucellosis (Cramlet \& Bernhanu, 1979).

b. Trauma is a major cause of predisposition of fistulous withers in horses hence proper fitting of saddle has to be taken care.

c. Parasitic problem Onchocerca spp. can also cause fistulous withers hence minimizing the parasitic load by proper hygienic measures needs to be practiced (Cramlet \& Bernhanu, 1979).

d. Many of the countries follow testing and quarantine the horses or euthanize the horse since brucellosis is zoonotic. Hence measures needs to be followed for early diagnosis of the disease so that horses can be segregated or culled to prevent further spread of the disease.

\section{Conclusion}

Brucellosis, an age old disease is one of the important zoonotic disease that can infect several domestic animals, wild animals and also marine mammals. Eleven brucella species have been 
described till date of which many are host restricted though it can infect other animals and also human. There is no single species of brucella that can cause brucellosis in equines. $B$. abortus and $B$. suis have been implicated to cause natural disease in equines. Mostly brucellosis in domestic animals are oriented to reproductive tract infection but in equines it causes mainly two important conditions affecting the musculoskeletal system termed as Poll evil and Fistulous withers. Abortions are also noticed in some cases but shedding of bacteria through the vaginal discharge is not documented yet. Though the disease has been reported for several years in horses there are still several questions that need to be clarified like the pathogenesis of bacterium in horse, predilection of bacterium towards musculoskeletal system in horse while mainly reproductive tract in other domestic animals. Diagnosis of brucellosis at the early stage is important to identify the diseased animals so that prior segregation of the animals can be done to minimize its spread to other animals. Advances in the field of diagnostics have made it possible to identify the agent early though proper sampling procedures needs to be practiced to achieve the same. Similarly treatment and vaccination aspects needs to be strengthened in order to control and eliminate the disease from the animal population so that its spread to humans can also be prevented.

\section{Conflict of interest}

Authors would hereby like to declare that there is no conflict of interests that could possibly arise.

\section{References}

Acha NP, Szyfres B (2003) Zoonoses and Communicable Diseases Common toe Man and Animals, third ed. Vol.1 Pan American Health Organization (PAHO), Washington, DC.

Acosta-Gonzalez RI, Gonzalez-Reyes I, Flores-Gutierrez GH (2006) Prevalence of Brucella abortus antibodies in equines of a tropical region of Mexico. Canadian Journal of veterinary Research 70: 302-304.

Adams LG (2002) The pathology of brucellosis reflects the outcome of the battle between the host genome and the Brucella genome. Veterinary Microbiology 90 : 553-61. DOI: 10.1016/S0378-1135(02)00235-3

Alton GG, Jones LM, Angus RD, Verger JM (1988) Techniques for the Brucellosis Laboratory. Institute National de la Recherche Agronomique, Paris, France. INRA. ISBN 27380-0042-8.

Amin AS, Hamdy ME, Ibrahim AK (2001) Detection of Brucella melitensis in semen using the polymerase chain reaction assay. Veterinary Microbiology 83: 37-44. DOI: 10.1016/S0378-1135(01)00401-1

Antunes JMAP, Allendorf SD, Appolinário CM, Peres MG, Perotta JH, Neves TB, Deconto I, Filho IRB, Biondo AW,
Megid J (2013) Serology for Brucella abortus in cart horses from an urban area in Brazil. Arquivo Brasileiro de Medicina Veterinária e Zootecnia 65 : 619-621. DOI: S010209352013000200044

Ardo MB, Abubakar DM (2016) Seroprevalence of horse (Equus caballus) brucellosis on the Mambilla plateau of Taraba State, Nigeria. Journal of Equine Veterinary Science 27 : 1-6. DOI: $10.1294 /$ jes.27.1

Ardo MB, Abubakar DM, Adamu Z (2016) Prevalence of Brucella antibodies in horses (Equus Caballus) in Jalingo, Taraba State, Nigeria. Journal of Public Health and Epidemiology 8 : 111- 114. DOI: 10.5897/JPHE2016.0811

Bale JO, Kwanashie GG (1984) Seroprevalence of bruellosis among horses in Northern Nigeria. Journal of Animal Production Research 4:161-164.

Bendrey R, Cassidy JP, Bokovenko N, Lepetz S, Zaitseva GI (2011) A Possible Case of 'Poll-Evil' in an Early Scythian Horse Skull from Arzhan 1, Tuva Republic, Central Asia. International Journal of Osteoarchaeology 21: 111-118.

Bertu WJ, Ocholi RA, Gusi AM, Abdullahi S, Zwandor NJ, Durbi IAA, Opara J, Okewole PA (2015) Brucella abortus infection in a multispecies livestock farm in Nigeria. International Journal of Biotechnology and Food Science 3: 36-40.

Bricker BJ (2002) PCR as a diagnostic tool for brucellosis. Veterinary Microbiology 90: 435-446. DOI: 10.1016/S03781135(02)00228-6

Brinley, Morgan WJ, Corbel MJ (1990) Brucella infections in man and animals: contagious equine metritis. In: Parker MT, Collier LH (Eds.), Topley and Wilson's principles of bacteriology, virology and immunology, 8th ed. Edward Arnold, London, England. Pp. 547-570.

Canning PC, Roth JA, Deyoe BL (1986) Release of $5 \alpha$ guanosine monophosphate and adenine by Brucella abortus and their role in the intracellular survival of the bacteria. Journal of Infectious Diseases 154: 464-470.

Carrigan MJ, Cockram FA, Nash GV (1987) Brucella abortus biotype 1 arthritis in a horse. Australian Veterinary Journal 64: 190. DOI: 10.1111/j.1751-0813.1987.tb09681.x

Cohen ND, Carter GK, McMullan WC (1992) Fistulous withers in horses: 24 cases (1984-1990). Journal of American Veterinary Medical Association 201: 121-124.

Colavita G, Amadoro C, Rossi F, Fantuz F, Salimei E (2016). Hygienic characteristics and microbiological hazard identification in horse and donkey raw milk. Veterinaria Italiana 52 : 21-29. DOI: 10.12834/VetIt.180.545.1. 
Collins JD, Kelly WR, Twomey T, Farrelly BT, Witty BT (1971) Brucella-associated vertebral osteomyelitis in a Thoroughbred mare. Veterinary Record 88: 321-326. DOI: $10.1136 / v r .88 .13 .321$

Corbel MJ, Henry DMFD (1983) Methods for the identification of Brucella. Ministry of Agriculture, Fisheries and Food, Alnwick, Northumberland p. 52.

Cramlet SH, Berhanu G (1979) The relationship of Brucella abortus titers to equine fistulous withers in Ethiopia. Veterinary Clinics of North America: Small Animal Practice 74: 195-199.

Crawford RP, Huber JD, Adams LG (1990) Epidemiology and surveillance. In: Animal Brucellosis, Eds: K. Nielsen and L. G. Adams, CRC Press, Orlando. pp 131-151.

Cvetnic Z, Spicic S, Curic S, Jukic B, Lojkic M, Albert D, Thiebaud M, Garin-Bastuji B (2005) Isolation of Brucella suis biovar 3 from horses in Croatia. Veterinary Record 156: 584585. DOI:10.1136/vr.156.18.584

DelVecchio VG, Kapatral V, Redkar RJ, Patra G, Mujer C, Los T, Ivanova N, Anderson I, Bhattacharyya A, Lykidis A, Reznik G, Jablonski L, Larsen N, D’Souza M, Bernal A, Mazur M, Goltsman E, Selkov E, Elzer PH, Hagius S, O'Callaghan D, Letesson JJ, Haselkorn R, Kyrpides N, Overbeek R (2002) The genome sequence of the facultative intracellular pathogen Brucella melitensis. Proceedings of the National Academy of Sciences 99: 443-448. DOI: 10.1073/pnas.221575398

Denny HR (1972) Brucellosis in the horse. Veterinary Record 90: 86-90. DOI: 10.1136/vr.90.4.86

Denny HR (1973) A review of brucellosis in the horse. Equine veterinary Journal 5: 121-125. DOI: 10.1111/j.20423306.1973.tb03208.x.

Dhama K, Karthik K, Chakraborty S, Tiwari R, Kapoor S, Kumar A, Thomas P (2013) Loop-mediated isothermal amplification of DNA (LAMP) - a new diagnostic tool lights the world of diagnosis of animal and human pathogens: a review. Pakistan Journal of Biological Sciences 17: 151-166. DOI: $10.3923 /$ pjbs.2014.151.166

Dorneles EMS, Fernandes LG, Santana JA, Freitas FJC, de Lima JM, Barros ID, Sakamoto SM, Heinemann MB, Lage AP (2013) Anti-Brucella abortus antibodies in free-ranging equids from Mossoró, Rio Grande do Norte, Brazil. Semina: Ciências Agrárias, Londrina. 34 : 1281-1286. DOI: 10.5433/16790359.2013v34n3p1281

Ehizibolo DO, Gusi MA, Ehizibolo PA, Mbuk EU, Ocholi RA (2011) Serologic prevalence of brucellosis in horse stables in two Northern states of Nigeria. Journal of Equine Sciences 22(1):17-19. DOI: $10.1294 /$ jes.22.17
Elfaki MG, Al-Hokail AA, Nakeeb SM, Al-Rabiah FA (2005) Evaluation of culture, tube agglutination and PCR methods for the diagnosis of brucellosis in humans. Medical Science Monitor 11 : MT69-74.

Fekete A, Bantle JA, Halling SM, Stich RW (1992) Amplification fragment length polymorphism in Brucella strains by use of polymerase chain reaction with arbitrary primers. Journal of Bacteriology 174: 7778-7783. DOI: 00219193/92/237778-06\$02.00/0

Foster G, Osterman BS, Godfrod J, Jacques I, Coekaert A (2007) Brucella cell sp. Nov. and Brucella pinnipedialis sp. Nov. for Brucella strains with cetaceans and seals as their preferred hosts. International Journal of Systemic and Evolutionary Microbiology 57: 2688-2693. DOI 10.1099/ijs.0.65269-0

Fretin D, Fauconnier A, Kohler S, Halling S, Leonard S, Nijskens C, Ferooz J, Lestrate P, Deirue RM, Danese I, Vandenhaute J, Tibor A, DeBolle X, Letesson JJ (2005) The sheathed flagellum of Brucella melitensis is involved in persistence in a murine model of infection. Cellular Microbiology 7: $\quad 6877-6980 . \quad$ DOI: $\quad 10.1111 / \mathrm{j} .1462-$ 5822.2005.00502.x

Gardner GR, Nicolleti P, Scarratt WK (1983) Treatment for brucellosis in horses by Florida practitioners. Florida Veterinary Journal 12: 21-23.

Gaughan EM, Fubini SL, Dietze A (1988) Fistulous withers in horses: 14 cases (1978-1987). Journal of American Veterinary Medical Association 193: 964- 966.

Ghobadi N, Salehi AR (2013) Evaluation Prevalence of Brucellosis in Horse Hamadan of Iran. International Journal of Agriculture and Crop Sciences 5 : 603-605.

Glynn MK, Lynn TV (2008) Brucellosis. Journal of American Veterinary Medical Association 233: 900-908. DOI: 10.2460/javma.233.6.900

Godfroid J, Cloeckaert A, Liautard JP, Kohler S, Fretin D, Walravens K, Garin-Bastuji B, Letesson JJ (2005) From the discovery of the Malta fever's agent to the discovery of a marine mammal reservoir, brucellosis has continuously been a re-emerging zoonosis. Veterinary Research 36: 313-326. DOI: 10.1051/vetres:2005003

Godfroid J, Kasbohrer A (2002) Brucellosis in the European Union and Norway at the turn of the twenty-first century. Veterinary Microbiology 90: 135-145. DOI: 10.1016/S03781135(02)00217-1

Godfroid J, Nielsen K, Saegerman C (2010) Diagnosis of Brucellosis in Livestock and Wildlife. Croatian medical journal 51 : 296-305. DOI: $10.3325 / \mathrm{cmj} .2010 .51 .296$ 
Gorvel JP, Moreno E (2002) Brucella intracellular life: from invasion to intracellular replication. Veterinary Microbiology 90: 281-297. DOI: 10.1016/S0378-1135(02)00214-6

Göz Y, Babür C, Aydin A, Kiliç S (2007) Seroprevalence of toxoplasmosis, brucellosis and listeriosis in horses in Hakkari, eastern region of Turkey. Revue de Médecine Vétérinaire 158 : 534-539.

Hagler DS, Nicoletti PL, Scarratt WK (1982) Attempt to infect horses with Brucella canis. Journal of Equine Veterinary Science 2: 168-169. DOI:10.1016/S0737-0806(82)80035-X

Hawkins JF, Fessler JF (2000) Treatment of supraspinous bursitis by use of debridement in standing horses: 10 cases (1968- 1999). Journal of American Veterinary Medical Association 217: 74-78.

Hinton M, Barker GL, Morgan TL (1977) Abortion in a mare associated with Brucella abortus infection and twins. Veterinary Record 101: 526.

Junqueira DG, Dorneles SEM, Santana JA, Almeida VMA, Nicolino RR, Silva MX, Mota ALAA, Veloso FP, Stynen APR, Heinemann MB, Lage AP (2015) Brucellosis in working equines of cattle farms from Minas Gerais State, Brazil. Preventive Veterinary Medicine 121 : 380-5. DOI: 10.1016/j.prevetmed.2015.06.008

Kanani AN (2007) Serological, Cultural and Molecular Detection of Brucella infection in Breeding Bulls. Ph.D thesis submitted to A. A. U., Anand.

Karthik K, Rathore R, Thomas P, Arun TR, Viswas KN, Agarwal RK, Manjunathachar HV, Dhama K (2014c) Loopmediated isothermal amplification (LAMP) test for specific and rapid detection of Brucella abortus in cattle. Veterinary Quarterly 34: 174-179. DOI: 10.1080/01652176.2014.966172

Karthik K, Rathore R, Thomas P, Arun TR, Viswas KN, Dhama K, Agarwal RK (2014b) New closed tube loop mediated isothermal amplification assay for prevention of product cross contamination. Methods X 1: e137-e143. DOI: 10.1016/j.mex.2014.08.009

Karthik K, Rathore R, Thomas P, Elamurugan A, Arun TR, Dhama K (2014a) Serological and molecular detection of Brucella abortus from cattle by RBPT, STAT and PCR, and sample suitability of whole blood for PCR. Asian Journal of Animal and Veterinary Advances 9: 262-269. DOI: 10.3923/ajava.2014.262.269

Karthik K, Rathore R, Thomas P, Viswas KN, Agarwal RK, Rekha V, Jagapur RV, Dhama K (2016) Rapid and visual loop mediated isothermal amplification (LAMP) test for the detection of Brucella spp. and its applicability in epidemiology of bovine brucellosis. Veterinarski Archive 86: 35-47.
Knottenbelt DC, Hill FW, Morton DJ (1989) Clofazimine for the treatment of fistulous withers in three horses. Veterinary Record 125: 509-10. DOI:10.1136/vr.125.20.509

Leal-Klevezas DS, Martinez VIO, Garcia CJ, Lopez MA, Martinez SJP (2000) Use of polymerase chain reaction to detect Brucella abortus biovar 1 in infected goats. Veterinary Microbiology 75: 91-97.

Lin GZ, Zheng FY, Zhou JZ, Gong XW, Wang GH, Cao XA, Qiu CQ (2011) Loop-mediated isothermal amplification assay targeting the omp25 gene for rapid detection of Brucella spp. Molecular and Cellular Probes 25: 126-129. DOI: 10.1016/j.mcp.2011.01.001.

Lucero NE, Ayala SM, Escobar GI, Jacob NR (2008) Brucella isolated in humans and animals in Latin America from 1968 to 2006. Epidemiology and Infection 136 : 496-503. DOI: $10.1017 /$ S0950268807008795

MacMillan AP, Baskerville A, Hambleton P, Corbel MJ (1982) Experimental Brucella abortus infection in the horse: observations during the three months following inoculation. Research in Veterinary Sciences 33: 351-359.

Macmillan AP, Cockrem DS (1985) Observations on long time effects of Brucella abortus infection in the horse including effects during pregnancy and lactation. Equine Veterinary Journal 18: 388-390.

MacMillan AP, Cockrem DS (1986) Observations on the longterm effects of Brucella abortus infection in the horse, including effects during pregnancy and lactation. Equine Veterinary Journal 18: 388- 390.

McCaughey WJ, Kerr WR (1967) Abortion due to brucellosis in a Thoroughbred mare. Veterinary Record 80: 186-187. DOI:10.1136/vr.80.5.186

McNutt SH, Murray C (1924) Bacterium abortion (Bang) isolated from the fetus of an aborting mare. Journal of American Veterinary Medical Association 97: 576-580.

Megid J, Mathias LA, Robles CA (2010) Clinical Manifestations of Brucellosis in Domestic Animals and Humans. The Open Veterinary Science Journal 4: 119-126. DOI: $10.2174 / 1874318801004010119$

Memish Z, Mah MW, Al Mahmoud S, Al Shaalan M, Khan MY (2000) Brucella bacteraemia: clinical and laboratory observations in 160 patients. Journal of Infection 40: 59-63.

Michaux S, Paillisson J, Carles-Nurit MJ, Bourg G, AllardetServent A, Ramuz M (1993) Presence of two independent chromosomes in the Brucella melitensis $16 \mathrm{M}$ genome. Journal of Bacteriology 175: 701-705. 
Michaux-Charachon S, Bourg G, Jumas-Bilak E, GuigueTalet P, Allardet-Servent A, O'Callaghan D, Ramuz M (1997) Genome structure and phylogeny in the genus Brucella. Journal of Bacteriology 179: 3244-3249.

Moreno E, Stackebrandt E, Dorsch M, Wolters J, Busch M, Mayer H (1990) Brucella abortus 16S rRNA and lipid A reveal a phylogenetic relationship with members of the alpha-2 subdivision of the class Proteobacteria. Journal of Bacteriology 172: 3569-3576.

Musa MT (2004) A Serological Study on Equine Brucellosis in Darfur, Western Sudan. The Sudan Journal of Veterinary Research 19: 7-11.

Neta AVC, Mol JPS, Xavier MN, Paixao TA, Lage AP, Santos RL (2010) Review: Pathogenesis of bovine brucellosis. The Veterinary Journal $184 \quad$ :146-55. DOI: 10.1016/j.tvj1.2009.04.010.

Nicoletti PL (2007) Brucellosis. In: Sellon DC, long MT (Eds.) Equine Infectious Diseases, Long, Saunders Elsevier, Philadelphia. Pp 348-350.

O'Sullivan BM (1981) Brucella abortus titres and bursitis in the horse. Australian Veterinary Journal 57: 103-104.

Ocholi RA, Bertu WJ, Kwaga JK, Ajogi I, Bale JO, Okpara J (2004) Carpal bursitis associated with Brucella abortus in a horse in Nigeria. Veterinary Record 155: 566-567.

Ohtsuki R, Kawamoto K, Kato Y, Shah MM, Ezaki T, Makino SI (2008) Rapid detection of Brucella spp. by the loop mediated isothermal amplification method. Journal of applied Microbiology 104: 1815-1823. DOI: 10.1111/j.13652672.2008.03732.x.

Pan W, Wang JY, Shen HY, Zhao MQ, Ju CM, Dong XY, Yi L, Chen JD (2011) Development and application of the novel visual loop mediated isothermal amplification of omp25 sequence for rapid detection of Brucella spp. Journal of Animal and Veterinary Advances 10: 2120-2126. DOI: 10.3923/javaa.2011.2120.2126

Pérez-sancho M, García-seco T, Arrogante L, García N, Martínez I, Diez-guerrier A, Perales A, Goyache J, Domínguez L, Alvarez J (2013) Development and evaluation of an IS711based loop mediated isothermal amplification method (LAMP) for detection of Brucella spp. on clinical samples. Research in Veterinary Sciences 95: 489-494. DOI: 10.1016/j.rvsc.2013.05.002.

Portugal MASC, Nesti A, Giorgi W, Franca EN, De Oliveira BS (1971) Brucelose em equideos determinada por Brucella suis. Arquivas di Instituto Biologica de Sao Paulo 38: 125-132.

Probert WS, Schrader KN, Khuong NY, Bystrom SL, Graves MH (2004) Real-time multiplex PCR assay for detection of
Brucella spp., B. abortus, and B. melitensis. Journal of Clinical Microbiology 42:1290- 1293. DOI: 10.1128/JCM.42.3.12901293.2004

Queipo-Ortuno MI, Colmenero JD, Reguera JM, Garc1'aOrdoñ ez, MA, Pacho'n, ME, Gonzalez M, Morata M (2005) Rapid diagnosis of hu-man brucellosis by SYBR Green I-based real-time PCR assay and melting curve analysis in serum samples. Clinical Microbiology and Infection 11: 713-718. DOI: 10.1111/j.1469-0691.2005.01202.x

Queipo-Ortuno MI, Morata P, Ocon P, Manchado P, Colmenero JD (1997) Rapid diagnosis of human brucellosis by peripheral- blood PCR assay. Journal of Clinical Microbiology 35: 2927-2930.

Quinn PJ, Carter ME, Markey B, Carter GR (2004) Clinical Veterinary Microbiology, Mosby, Edinburgh, pp. 168-172; 261-267.

Radostits OM, Gay CC, Blood DC, Hinchcliff KW (2000) Veterinary Medicine, 9th Ed., ELBS Bailliere Tindall, London, UK, pp: 870-871.

Rashmir-Raven A, Gaughan EM, Modransky P (1990) Fistulous withers. Compendium on Continuing Education for the Practising Veterinarian 12: 1633-1641.

Rhyan JC (2000) Brucellosis in terrestrial wildlife and marine mammals. In: Brown C, Bolin C (Eds. ) Emerging diseases of animals, 1st Ed. ASM Press, Washington, DC, 161-184.

Riley LK, Robertson DC (1984) Ingestion and intracellular survival of Brucella abortus in human and bovine polymorphonuclear leukocytes. Infection and Immunity $46: 224-230$

Robertson FJ, Milne J, Silver CL, Clark H (1973) Abortion associated with Brucella abortus (biotype 1) in the T.B. mare. Veterinary Record 92: 480-481.

Roop II RM, Bellaire BH, Valderas MW, Cardelli JA (2004) Adaptation of the Brucellae to their intracellular niche. Molecular Microbiology 52: 621-630. DOI: 10.1111/j.13652958.2004.04017.x

Sadiq MA, Tijjani AN, Auwal MS, Mustapha AR, Tijjani AO, Gulani I, Mohammed A (2013) Prevalence of Brucella antibodies in donkeys (Equus asinus) in Borno and Yobe states, Nigeria. Sokoto Journal of Veterinary Sciences 11: 712. DOI: $10.4314 /$ sokjvs.v11i1.2.

Safirullah, Anwar K, Abdur-Raziq, Shahid M, Raza S, Khan N, Amin Y (2014) Epidemiological Study of Brucellosis in Equines of District Peshawar Khyber Pakhtunkhwa Pakistan. International Journal of Current Microbiology and Applied Sciences 3: 795-800. 
Sanchez DO, Zandomeni RO, Cravero S, Verdun RE, Pierrou E, Faccio P, Diaz G, Lanzavecchia S, Aguero F, Frasch AC (2001). Gene discovery through genomic sequencing of Brucella abortus. Infection and Immunity 69:865-868. DOI: 10.1128/IAI.69.2.865-868.2001

Scholz HC, Hubalek Z, Sedlacek I, Vergnaud G, Tamaso H, Al Dahouk S, Melzer F, Kampfer P, Neubauer H, Cloeckaert A, Maquart M, Zygmunt MS, Whatmore AM, Falsen E, Bahn P, Gollner C, Pfeffer M, Huber B, Busse HJ, Nockler K (2008) Brucella microti sp. Nov. isolated from the common vole Microtus arvalis. International Journal of Systematic and Evolutionary Microbiology 58: 375-382. DOI: 10.1099/ijs.0.65356-0.

Shortridge EH (1967) Two cases of suspected Brucella abortus abortion in mares. New Zealand Veterinary Journal 15: 33-34. DOI: $10.1080 / 00480169.1967 .33683$
Solmaz H, Tutuncu M, Akkan HA, Aksakal A, Gulhan T, Boynukara B (2004) Brucellosis in horses around Van, Turkey. Indian Veterinary Journal 81: 748-749.

Tahamtan Y, Namavari MM, Mohammadi G, Jula GM (2010) Prevalence of Brucellosis in Horse North-East of Iran. Journal of Equine Veterinary Sciences 30 : 376-78. DOI: http://dx.doi.org/10.1016/j.jevs.2010.05.007

Tel OY, Arserim NB, Keskin O (2011) Seroprevalence of Equine Brucellosis in Southeast Turkey. YYU Veteriner Fakultesi Dergisi 22(3): $181-183$.

Verger JM, Grimont F, Grimont PA, Grayon M (1987) Taxonomy of the genus Brucella. Annales de l'Institut Pasteur / Microbiologie 138: 235-238. 